The Truth Project

Authors: David M. Markowitz ${ }^{*}$, Kate G. Blackburn ${ }^{2}$, Keya Saxena ${ }^{1}$, Jade Marion², Omar Olivarez $^{2}$, Rebecca Hernandez ${ }^{2}$, Michael T. Woodworth ${ }^{3}$, \& Jeffrey T. Hancock ${ }^{4}$

${ }^{1}$ School of Journalism and Communication, University of Oregon, Eugene, OR USA

${ }^{2}$ Department of Psychology, University of Texas at Austin, Austin, TX USA

${ }^{3}$ Department of Psychology, University of British Columbia Okanagan, Kelowna, BC Canada

${ }^{4}$ Department of Communication, Stanford University, Stanford, CA USA 


\begin{abstract}
The United States Constitution grants Americans the "right to a speedy and public trial," with an assumption that the trial is impartial and fair. Recent data suggest a nontrivial number of cases fail to meet this standard. During interrogations, suspects can be presented with false evidence, long interrogations can undermine a suspect's cognitive ability, and minimization tactics often mislead suspects into believing justice is on their side. These dynamics facilitate false confessions and wrongful convictions, which are common in the United States and globally. We argue that the current approaches to understand and predict innocence in legal cases are insufficient and interdisciplinary research is required to prevent innocent people from going to jail. In this review, we cover research on wrongful convictions and false confessions, ending with The Truth Project (www.truth-project.io), a new global framework to connect scholars and facilitate research into behavioral patterns of innocence.
\end{abstract}

Keywords: innocence, wrongful convictions, false confessions, interrogations, truth project 


\section{The Truth Project}

Since 1989, over 2,700 individuals have been exonerated in the United States after cumulatively spending nearly 24,770 years in prison as victims of wrongful convictions (National Registry of Exonerations, 2021). While wrongful conviction cases have long been a focus of legal scholarship, they have only recently been brought to public attention through documentaries and entertainment. For example, When They See Us provides a harrowing story of the conviction and exoneration of five African American teenagers in the US, while highlighting a common contributing factor of wrongful convictions: false confessions.

Considering that $95 \%$ of criminal convictions are determined by guilty pleas rather than court verdicts (Zimmerman \& Hunter, 2018), confessions play a major role in the American judicial system. To deconstruct the grievous phenomena of false confessions and wrongful convictions, it is necessary to address several key questions: How are true and false confessions different, and what behavioral traces betray them? What methods or tools can help to distinguish true from false confessions? We propose using computational approaches to understand the psychology of innocence, particularly through the lens of language patterns. In this piece, we review work on wrongful convictions and false confessions to describe the gravity of such issues and how academic communities have investigated them. We conclude with a framework — The Truth Project - to connect scholars from around the world to take a greater academic interest in wrongful convictions and to collectively work toward the goal of preventing wrongful convictions. This framework is a collaborative mechanism that we hope focuses and more widely popularizes the study of wrongful convictions across different academic communities.

\section{Wrongful Convictions: An Academic Overview}

A wrongful conviction occurs when available evidence suggests an individual is factually 
innocent of a crime, but they are still imprisoned (Cornell Center on the Death Penalty Worldwide, 2018). Wrongful convictions and executions are a global issue (Amnesty International, 2016), but most attention has focused on cases involving Americans due to their high-profile nature (Knox, 2015; Salaam et al., 2021; Stevenson, 2014) and the United States having the largest prison population in the world (World Prison Brief, 2021).

The earliest cataloguing and study of wrongful convictions began in the 1930s. A seminal text by Borchard (1932), for example, documented sixty-five cases where defendants were wrongfully prosecuted and convicted in the United States. Borchard's work shifted the question of whether innocent people were wrongfully convicted (e.g., if the phenomenon was pervasive) to why they were wrongfully incarcerated, including policy recommendations for the American criminal justice system (e.g., compensation for the wrongfully convicted). Despite this early work, wrongful convictions remain a stain on judicial systems around the world because a nontrivial number of innocents are put in jail.

False confessions. Perhaps the most important and counterintuitive wrongful convictions occur after a defendant admits to a crime they never committed. Confessing to a crime, in general, is nearly catastrophic for a defendant's chance at innocence (McCormick, 1972) and therefore, a false confession is the defendant doing the prosecution's job for them. In other words, a false confession tips the scale of justice in favor of the prosecution, undermines the defendant's autonomy, and is directly linked to wrongful convictions.

Nearly one-third of wrongful convictions include false confessions (Kassin, 2014), but beyond prevalence rates, it is important to assess who tends to falsely confess most often. A case with traits that are typical of false confessions includes The Central Park Five. Here, young African American men were misled and coerced by police to falsely admit to the sexual assault 
and attempted murder of a White woman. Like this case, false confessions often originate from people who are under 18 years old (Drizin \& Leo, 2004) and ethnic minorities (Grimsley, 2012). False confessions also tend to come from psychologically vulnerable suspects or defendants (Gudjonsson, 2003; Gudjonsson \& Pearse, 2011). Therefore, specific dispositional traits are associated with falsely confessing to a crime (Kassin et al., 2010; Perillo \& Kassin, 2011).

Situational characteristics can also facilitate false confessions and wrongful convictions (Kassin et al., 2010). In the process of being interrogated, people are often isolated from familiar surroundings, presented with false evidence (at least in the United States), and in some cases, threatened if they do not comply with law enforcement. Minimization tactics are also used, such as offering sympathy to a suspect (Kassin et al., 2018), which can make them less resistant to confessing (Luke \& Alceste, 2020). When false evidence is presented to suspects, this can create false memories. Further, when people distrust their own memory about an event, they become susceptible to pressure from outside forces and can invent stories (Gudjonsson, 2017). False memories can be produced in the lab (Shaw \& Porter, 2015) and during actual interrogations (Kassin, 2017), suggesting false confessions are even possible for those who might not fit the characteristics of a vulnerable suspect (e.g., young, ethnic minorities).

Finally, false confessions may be facilitated by the nature of innocence and the belief of being an innocent person (Kassin, 2012). Innocence is a liability because innocent people are often convinced the justice system will work in their favor, jurors will see the evidence clearly, investigative tactics will be honest, and the law will be on their side. Innocent people know the truth, and allegiance to it might affect their judgments or decision-making as the suspect of a legal case (e.g., believing that the "truth will set you free" can backfire).

Taken together, dispositional, situational, and phenomenological aspects of false 
confessions increase the likelihood of wrongful convictions (Scherr et al., 2020). While false confessions represent a portion of why defendants are wrongfully convicted, they are some of the most important to investigate because steps can be taken to reduce the chances that a person admits to a crime they never committed. For example, interrogations occur behind closed doors and this privacy is a risk factor for suspects. Therefore, to improve the transparency of the interrogation process, Kassin and colleagues (Kassin et al., 2010) recommend taping all interrogations. This evidence can serve as ground truth for events when suspects are questioned by police. The presentation of false evidence within an interrogation, the length of an interrogation, and tactics to minimize the severity of the situation also put innocent people at risk. Currently, policies around interrogations are regionally defined and no standard exists on how to treat suspects during an interrogation.

While false confessions have "become a mature subdiscipline of psychology" and some evidence-based recommendations have directly impacted legal policy (Schmidt, 2014), we argue that an understanding of wrongful convictions (and false confessions) requires a greater interdisciplinary empirical effort that focuses on the confessions and testimonies directly (Kassin, 2017, p. 954). We advocate for psychologists, communication researchers, computer scientists, and legal scholars to use evidence from the court room to understand how innocence unfolds and is communicated. One way to accomplish this is to investigate innocence through the examination of language patterns, particularly by using court transcripts. Given the composition of the current authorship team, we focus on analyzing transcript language patterns through automated means. There are other data in case files, however, that could be useful to understand how wrongful convictions happen as well. For example, case file data would contain the time of day for a court case, how a lawyer's statements impacted a defendant's response, and 
how judges impact sentencing. When combined with language patterns from transcripts, these data can help to provide a holistic view of the processes that might facilitate wrongful convictions. In the proceeding sections, we discuss how language is generally used to identify deception outside of legal settings and conclude with a pathway to encourage the study of wrongful convictions and false confessions more broadly.

\section{Language as a Lens into Deception and Wrongful Convictions}

In the last decade, automated text analysis approaches have introduced reliable ways to track words over large corpora of text. Some of these methods have demonstrated that by counting the different types of words for a given text, it is possible to identify one's gender (Burger et al., 2011), emotional state (Vine et al., 2020), and personality type (Yarkoni, 2010). A small group of studies have focused on the analysis of function words - words unrelated to the content of speech - that include pronouns (e.g., I, me, she), articles (e.g., a, the), prepositions (e.g., above, below), and auxiliary verbs (e.g., been, had). Indeed, word patterns have been a useful lens to evaluate psychological processes such as deception (Hauch et al., 2015; Markowitz \& Hancock, 2016; Nahari et al., 2019), which is closely related to the issue of false confessions and wrongful convictions. Liars tend to use fewer self-references when proving deceptive accounts of events compared to truth-tellers (Knapp et al., 1974), describing opposing viewpoints (Markowitz \& Griffin, 2020; Newman et al., 2003), committing corporate fraud (Taylor et al., 2013), and falsifying information (Bond \& Lee, 2005). This shift away from selfreferences is thought to redirect attention from the self to others and signal their decreased selfinvolvement (Newman et al., 2003).

Although automated text analysis and deception research has largely focused on pronouns, other language markers are just as important to understand the perceptions and 
behaviors of individuals when they communicate falsely. Notably, people who provide false confessions or memories often modify details (Shaw \& Porter, 2015), thereby changing their use of prepositions, articles, and occasionally their use of negatively-valenced words (Newman et al., 2003). Researchers speculate that these language patterns emerge as people try to distance themselves from the lie, or deceptively cloak their thoughts and behaviors (Vrij et al., 2017).

It should be noted, however, that deception studies in general suffer from several challenges (Levine, 2018). Studies often seek to identify whether someone is telling the truth in a controlled setting or interview (Nahari et al., 2012). Another challenge is that these studies often involve low-risk situations without real-world consequences, such as jail time. In a very real way, this research had failed to consider the scope or context-contingent nature of deception (for a review, see Markowitz, 2020; Markowitz \& Hancock, 2019).

This is even true for more traditional lines of deception research, which measures deception in the context of guilty knowledge tests (Hu et al., 2015), cognitive (Vrij et al., 2008) and accusatorial interviews (Meissner et al., 2014), and non-verbal cues (Toma et al., 2008). In fact, an overwhelming number of deception studies have relied on well-controlled designs with college students where the stakes of being caught are minimal. Similar to parlor games, most well-controlled studies are only able to identify lies from truth at rates between $53-70 \%$, where $50 \%$ is chance (Levine, 2020). Whereas most deception research has focused on nonverbal behaviors or physiological activity, comparatively less work has focused on language patterns. Given these challenges, there has been a call by law enforcement officials to concentrate on the language used in settings that facilitate the confession process, such as interviews, or information gathering sessions with people of interest (Meissner et al., 2010). In addition to identifying 
language markers that predict deception, an equally important approach is to detect when people are telling the truth.

\section{The Language of Innocence}

The study of language in false and truthful confessions has a long history (Shuy, 1998), yet two studies stand out as recent investigations into the content patterns of innocence from actual court transcripts. First, researchers evaluated 20 false confession cases that resulted from police-induced confessions and when the means of exoneration included DNA evidence, the case was overturned by appeal, or another perpetrator was found (Appleby et al., 2013). The authors performed a content analysis of the confessions and observed that defendants told rich stories about who participated in a crime, when it occurred, and how the crime transpired. Crucially, these confessions also included rich auditory and visual information of a crime, and the individual's inner dialogue (e.g., their false psychological experience recalling the crime). Therefore, false confessions are more than "admissions of guilt," offering a window into the psychology of an innocent person when they falsely admit to a crime (Appleby et al., 2013) (p. 116). A second example by Garrett (2010) investigated 40 cases and came to similar conclusions as Appleby and colleagues: false confessions contain rich details that are often fed to suspects and defendants by police (see also Garrett, 2015).

While these studies provide a useful starting point to investigate the psychology of innocence via language patterns, they are constrained in several ways. First, there are a limited number of investigated cases in such examples, and they lack control groups (e.g., actual criminals to compare against those who were wrongfully convicted). To evaluate how well these effects hold and scale across countries, time, and conviction types, more interdisciplinary work is required. Second, these studies also predominantly use content patterns to identify false 
confessions but ignore psychologically rich patterns of function words (e.g., pronouns). Function words are crucial indicators of deception and psychological characteristics (Hauch et al., 2015); therefore, they should also be investigated in linguistic evaluations of innocence to separate genuine from false confessions (and subsequent wrongful convictions).

\section{The Truth Project: A Call to Action}

The Innocence Project and Equal Justice Initiative fight for fair trials and to overturn wrongful convictions. These trailblazing organizations are legal entities doing the hard work to exonerate those who should never have been jailed. Still, many innocent people remain incarcerated, and their cases need to be reevaluated and reconsidered from a new perspective with the support of academic institutions. It is an opportunity, and in some respects, a duty, of scientists to use their expertise and passion for inquiry to address problems of such great societal importance. The wrongfully convicted need representation in academia, and we need to understand innocence before sentencing to prevent the incarceration of blameless people.

Here, we introduce The Truth Project (www.truth-project.io), a collaboration between social scientists to provide a platform for academic investigations into wrongful convictions. We intend to use this platform to collect and track research on wrongful convictions, and to develop new insights into the process of innocent people going to jail. Our primary interest, given the composition of the authorship team, is in language patterns and using the transcripts of wrongfully convicted people to create a psychological profile of innocence. If these data are predictive, they might be useful evidence in court. Other scientists, legal scholars, or practitioners might use case file data, language, and other metadata to forecast innocence from their own perspective. We envision The Truth Project as a symbiotic place for research and application: scholars and advocates can submit client case files, transcripts, and other materials 
to conduct empirical research, while lawyers and practitioners can use evidence from this database to assist with legal proceedings.

To do this, The Truth Project has developed short and long-term goals. In the short term, we hope to provide a space that allows data to be housed in a single location, which will facilitate other projects using the collated data. By organizing a publicly accessible hub of information, costly research barriers will be reduced. However, this initial goal will require stakeholder commitment. For instance, if researchers, lawyers, or legal scholars have case file data, we encourage them to use our site and submit a request to have these files securely transferred to our research team. We hope to create the largest repository of international case files and transcripts to be used for research purposes - exonerations are not required to be facilitated by DNA evidence alone. In turn, these data will help to conduct empirical work on wrongful convictions and mitigate the number of people who are incorrectly incarcerated.

A long-term goal is to restructure legal processes, including but not limited to making transcripts of confessions both false and guilty available to the public. Other organizations provide access to data on exonerees (Innocence Record, 2021), but no mechanism exists to analyze or interpret this data for research or application purposes. The Truth Project can be this mechanism. Systemic problems require creative and collective responses. We urge colleagues across fields and interests to join our efforts, submit their data to the project for scientific research, and become a community of scholars invested in pursuing scientific knowledge that might prevent future wrongful incarcerations.

\section{Conclusion}

Innocent people should never be incarcerated. Judicial systems around the world fail to make this truth a reality, suggesting the processes and institutions facilitating wrongful 
convictions need greater examination. For readers new to wrongful convictions and false confessions, we hope this paper and initiative provides important grounding into this research area and offers connections to their own work. For readers actively researching wrongful convictions and false confessions in disparate fields, we hope this paper serves as a "call to action" for greater interdisciplinary collaboration and community-building toward the goal of reducing global wrongful conviction rates. Text analysis is just one way to evaluate how innocence is associated with human behavior and we hope diverse collaborations will help to evaluate this phenomenon from a range of perspectives.

\section{Acknowledgments}

We thank Marissa Padilla, David Menashe, Britta Bauer, Kyle Stipe and Jamie Pennebaker for their feedback on this paper and conversations about wrongful convictions. 


\section{References}

Amnesty International. (2016). Death sentences and executions: 2016.

Appleby, S. C., Hasel, L. E., \& Kassin, S. M. (2013). Police-induced confessions: an empirical analysis of their content and impact. Psychology, Crime \& Law, 19(2), 111-128. https://doi.org/10.1080/1068316X.2011.613389

Bond, G. D., \& Lee, A. Y. (2005). Language of lies in prison: Linguistic Classification of prisoners' truthful and deceptive natural language. Applied Cognitive Psychology, 19(3), $313-329$.

Borchard, E. M. (1932). Convicting the innocent: Sixty-five actual errors of criminal justice. Yale University Press.

Burger, J. D., Henderson, J., Kim, G., \& Zarrella, G. (2011). Discriminating gender on Twitter. Proceedings of the 2011 Conference on Empirical Methods in Natural Language Processing, 1301-1309. https://www.aclweb.org/anthology/D11-1120

Cornell Center on the Death Penalty Worldwide. (2018). Justice denied: A global study of wrongful death row convictions.

Drizin, S. A., \& Leo, R. A. (2004). The problem of false confessions in the post-DNA world. North Carolina Law Review, 82, 891-1007. https://heinonline.org/HOL/Page?handle=hein.journals/nclr82\&id=905\&div=\&collection=

Garrett, B. L. (2010). The substance of false confessions. Stanford Law Review, 62(4), 10511118.

Garrett, B. L. (2015). Convicting the innocent redux. In D. Medwed (Ed.), Wrongful convictions and the DNA revolution: Twenty-five years of freeing the innocent. Cambridge University Press. 
Grimsley, E. (2012, September 26). What wrongful convictions teach us about racial inequality. https://innocenceproject.org/what-wrongful-convictions-teach-us-about-racial-inequality/

Gudjonsson, G. H. (2003). The psychology of interrogations and confessions: A handbook. Wiley.

Gudjonsson, G. H. (2017). Memory distrust syndrome, confabulation and false confession. Cortex, 87, 156-165. https://doi.org/10.1016/j.cortex.2016.06.013

Gudjonsson, G. H., \& Pearse, J. (2011). Suspect interviews and false confessions. Current Directions in Psychological Science, 20(1), 33-37. https://doi.org/10.1177/0963721410396824

Hauch, V., Blandón-Gitlin, I., Masip, J., \& Sporer, S. L. (2015). Are computers effective lie detectors? A meta-analysis of linguistic cues to deception. Personality and Social Psychology Review, 19(4), 307-342. https://doi.org/doi:10.1177/1088868314556539

Hu, X., Bergström, Z. M., Bodenhausen, G. V., \& Rosenfeld, J. P. (2015). Suppressing unwanted autobiographical memories reduces their automatic influences: Evidence from electrophysiology and an implicit autobiographical memory test. Psychological Science, 26(7), 1098-1106. https://doi.org/10.1177/0956797615575734

Innocence Record. (2021). The innocence record. https://www.innocencerecord.org/Pages/Home.aspx?ReturnUrl=\%2F_layouts\%2FAuthentic ate.aspx $\% 3 \mathrm{FSource} \% 3 \mathrm{D} \% 252 \mathrm{f} \&$ Source $=\% 2 \mathrm{~F}$

Kassin, S. M. (2012). Why confessions trump innocence. American Psychologist, 67(6), 431445. https://doi.org/10.1037/a0028212

Kassin, S. M. (2014). False confessions: Causes, consequences, and implications for reform. Policy Insights from the Behavioral and Brain Sciences, 1(1), 112-121. 
https://doi.org/10.1177/2372732214548678

Kassin, S. M. (2017). False confessions: How can psychology so basic be so counterintuitive? American Psychologist, 72(9), 951-964. https://doi.org/10.1037/amp0000195

Kassin, S. M., Drizin, S. A., Grisso, T., Gudjonsson, G. H., Leo, R. A., \& Redlich, A. D. (2010). Police-induced confessions: Risk factors and recommendations. Law and Human Behavior, 34(1), 3-38. https://doi.org/10.1007/s10979-009-9188-6

Kassin, S. M., Redlich, A. D., Alceste, F., \& Luke, T. J. (2018). On the general acceptance of confessions research: Opinions of the scientific community. American Psychologist, 73(1), 63-80. https://doi.org/10.1037/amp0000141

Knapp, M. L., Hart, R. P., \& Dennis, H. S. (1974). An exploration of deception as a communication construct. Human Communication Research, 1(1), 15-29.

Knox, A. (2015). Waiting to be heard: A Memoir. HarperCollins Publishing.

Levine, T. R. (2018). Ecological validity and deception detection research design. Communication Methods and Measures, 12(1), 45-54. https://doi.org/10.1080/19312458.2017.1411471

Levine, T. R. (2020). Duped: Truth-Default Theory and the social science of lying and deception. University of Alabama Press.

Luke, T. J., \& Alceste, F. (2020). The mechanisms of minimization: How interrogation tactics suggest lenient sentencing through pragmatic implication. Law and Human Behavior, 44(4), 266-285. https://doi.org/10.1037//hb0000410

Markowitz, D. M. (2020). The deception faucet: A metaphor to conceptualize deception and its detection. New Ideas in Psychology, 59, 100816. https://doi.org/10.1016/j.newideapsych.2020.100816 
Markowitz, D. M., \& Griffin, D. J. (2020). When context matters: How false, truthful, and genrerelated communication styles are revealed in language. Psychology, Crime \& Law, 26(3), 287-310. https://doi.org/10.1080/1068316X.2019.1652751

Markowitz, D. M., \& Hancock, J. T. (2016). Linguistic obfuscation in fraudulent science. Journal of Language and Social Psychology, 35(4), 435-445. https://doi.org/10.1177/0261927X15614605

Markowitz, D. M., \& Hancock, J. T. (2019). Deception and language: The Contextual Organization of Language and Deception (COLD) framework. In T. Docan-Morgan (Ed.), The palgrave handbook of deceptive communication (pp. 193-212). Palgrave Mcmillan.

McCormick, C. T. (1972). Handbook of the law of evidence (2nd ed.). West.

Meissner, C. A., Redlich, A. D., Michael, S. W., Evans, J. R., Camilletti, C. R., Bhatt, S., \& Brandon, S. (2014). Accusatorial and information-gathering interrogation methods and their effects on true and false confessions: a meta-analytic review. Journal of Experimental Criminology, 10(4), 459-486. https://doi.org/10.1007/s11292-014-9207-6

Nahari, G., Ashkenazi, T., Fisher, R. P., Granhag, P.-A., Hershkowitz, I., Masip, J., Meijer, E. H., Nisin, Z., Sarid, N., Taylor, P. J., Verschuere, B., \& Vrij, A. (2019). 'Language of lies': Urgent issues and prospects in verbal lie detection research. Legal and Criminological Psychology, 24(1), 1-23. https://doi.org/10.1111/1crp.12148

Nahari, G., Vrij, A., \& Fisher, R. P. (2012). Does the truth come out in the writing? Scan as a lie detection tool. Law and Human Behavior, 36(1), 68-76. https://doi.org/10.1037/h0093965

National Registry of Exonerations. (2021, February 1). The national registry of exonerations. http://www.law.umich.edu/special/exoneration/Pages/about.aspx

Newman, M. L., Pennebaker, J. W., Berry, D. S., \& Richards, J. M. (2003). Lying words: 
Predicting deception from linguistic styles. Personality and Social Psychology Bulletin, 29(5), 665-675. https://doi.org/10.1177/0146167203029005010

Perillo, J. T., \& Kassin, S. M. (2011). Inside interrogation: The lie, the bluff, and false confessions. Law and Human Behavior, 35(4), 327-337. https://doi.org/10.1007/s10979$010-9244-2$

Salaam, Y., Richardson, K., \& Santana, R. (2021). We are the 'Exonerated 5.' What happened to us isn't past, it's present. The New York Times. https://www.nytimes.com/2021/01/04/opinion/exonerated-five-false-confessions.html

Scherr, K. C., Redlich, A. D., \& Kassin, S. M. (2020). Cumulative disadvantage: A psychological framework for understanding how innocence can lead to confession, wrongful conviction, and beyond. Perspectives on Psychological Science, 15(2), 353-383. https://doi.org/10.1177/1745691619896608

Schmidt, M. S. (2014, May 22). In policy change, justice dept. to require recording of interrogations. The New York Times. https://www.nytimes.com/2014/05/23/us/politics/justice-dept-to-reverse-ban-on-recordinginterrogations.html

Shaw, J., \& Porter, S. (2015). Constructing rich false memories of committing crime. Psychological Science, 26(3), 291-301. https://doi.org/10.1177/0956797614562862

Shuy, R. W. (1998). The language of confession, interrogation, and deception. In The Language of Confession, Interrogation, and Deception. SAGE Publications, Inc. https://doi.org/10.4135/9781452229133

Stevenson, B. A. (2014). Just mercy: A story of justice and redemption. Spiegel \& Grau. Taylor, P. J., Dando, C. J., Ormerod, T. C., Ball, L. J., Jenkins, M. C., Sandham, A., \& 
Menacere, T. (2013). Detecting insider threats through language change. Law and Human Behavior, 37(4), 267-275. https://doi.org/10.1037/lhb0000032

Toma, C. L., Hancock, J. T., \& Ellison, N. B. (2008). Separating fact from fiction: An examination of deceptive self-presentation in online dating profiles. Personality and Social Psychology Bulletin, 34(8), 1023-1036. https://doi.org/10.1177/0146167208318067

Vine, V., Boyd, R. L., \& Pennebaker, J. W. (2020). Natural emotion vocabularies as windows on distress and well-being. Nature Communications, 11(1), 1-9. https://doi.org/10.1038/s41467-020-18349-0

Vrij, A., Fisher, R., Mann, S., \& Leal, S. (2008). A cognitive load approach to lie detection. Journal of Investigative Psychology and Offender Profiling, 5(1-2), 39-43. https://doi.org/10.1002/jip.82

Vrij, A., Meissner, C. A., Fisher, R. P., Kassin, S. M., Morgan, C. A., \& Kleinman, S. M. (2017). Psychological perspectives on interrogation. Perspectives on Psychological Science, 12(6), 927-955. https://doi.org/10.1177/1745691617706515

World Prison Brief. (2021). World Prison Brief data. https://www.prisonstudies.org/worldprison-brief-data

Yarkoni, T. (2010). Personality in 100,000 Words: A large-scale analysis of personality and word use among bloggers. Journal of Research in Personality, 44(3), 363-373. https://doi.org/10.1016/j.jrp.2010.04.001

Zimmerman, D. M., \& Hunter, S. (2018). Factors affecting false guilty pleas in a mock plea bargaining scenario. Legal and Criminological Psychology, 23(1), 53-67. https://doi.org/10.1111/lcrp.12117 